\section{Anesthetic Management of Three Parturients With von Willebrand Disease}

Gözde İnan (1) Naciye Türk Özterlemez (1)

Melis Altuğ (D)

Dudu Berrin Günaydın (1)

\title{
Von Willebrand Hastalığı Olan Üç Gebenin Anestezi Yönetimi
}

\section{ABSTRACT}

Von Willebrand Disease ( $(W D D)$ cases with bleeding symptoms can be admitted repetitively and anesthesia is required for minor or major surgery. We aimed to present anesthetic management of three patients with vWD and their post-operative follow up by discussing it in accordance with the literature. Any patient with vWD scheduled for surgery and/or delivery needs careful antenatal evaluation and long lasting postpartum follow up in a tertiary care center by multidisciplinary approach where blood and/or factor concentrates readily available.

Keywords: von Willebrand Disease, surgery; cesarean or delivery

öz

Kanama semptomları olan von Villebrand hastalıklı olgular, sık hastaneye başvurduklarından minor veya major cerrahi için anestezi gerekir. Von Villebrand hastalığı olan üç olgunun anestezi yönetimini ve postoperatif takibini literatür eşliğinde tartışarak sunmayı amaçladık. Cerrahi ve/ veya doğum yapacak von Willebrand hastalıklı kişilerin kan ve/veya faktör konsantrelerinin hazır bulunduğu 3.basamak bir merkezde multidisipliner yaklaşımla dikkatli antenatal değerlendirme ve uzun süreli postpartum takibi gerekir.

Anahtar kelimeler: von Villebrand hastalığı, cerrahi, sezaryen veya doğum
Received/Geliş: 26 August 2021 Accepted/Kabul: 02 September 2021 Publication date: 27 September 2021

Cite as: İnan G, Türk Özterlemez N, Altuğ M, Günaydın DB. Anesthetic management of three parturients with von Willebrand disease. JARSS 2021;29(4):279-82.

Dudu Berrin Günaydın Gazi Üniversitesi Tıp Fakültesi Anesteziyoloji Anabilim Dalı, Ankara, Türkiye

gunaydin@gazi.edu.tr ORCID: 0000-0002-0422-5536

G. İnan 0000-0003-0989-1914 N. Türk Özterlemez 0000-0002-7030-5411 Gazi Üniversitesi Tıp Fakültesi Anesteziyoloji Anabilim Dalı, Ankara, Türkiye

M. Altuğ 0000-0001-5054-1292 Gazi Üniversitesi Tıp Fakültesi Kadın Hastalıkları ve Doğum Anabilim Dalı, Ankara, Türkiye

\section{INTRODUCTION}

Von Willebrand disease ( $v W D$ ) is the most common hereditary bleeding disorder with a prevalence of 0.6$1.3 \%{ }^{(1)}$. Defective platelet adhesion and aggregation are the main characteristics of the disease. Patients with vWD presents mucosa-associated bleeding after surgery and trauma. Personal or family history of abnormal bleeding is related to decreased von Willebrand factor (vWF) and/or factor VIII (FVIII) (2). Administration of exogenous VWF concentrate or desmopressin (DDVAP) are used to increase the level of VWF levels. Due to the physiologic changes of pregnancy in coagulation, FVIII and vWF levels can reach as high as $250 \%$ particularly near term, and rapidly decreases following delivery to return baseline in 6 weeks. So pregnant women need careful preoperative evaluation and follow up ${ }^{(3)}$. We aimed to share our anesthetic management of three patients with vWD.

Case report: Informed consents were obtained from patients.

Case 1; a 24 year-old term parturient with previous abortus imminens history underwent cesarean section (CS). Patient's laboratory results were presented in Table I. Patient received preoperatively vWF/factor VIII concentrate of $40 \mathrm{IU} \mathrm{kg}^{-1}$ and had CS under general anesthesia, with intravenous (IV) propofol $2 \mathrm{mg} \mathrm{kg}^{-1}+100 \mu \mathrm{g}$ fentanyl $+0.5 \mathrm{mg} \mathrm{kg}^{-1}$ rocuronium followed by intubation with $7.0 \mathrm{~mm}$ 
cuffed tube, and anesthesia was maintained with sevoflurane 1 MAC in 50\% oxygen-air mixture. Extubation was performed using sugammadex IV 2 $\mathrm{mg} \mathrm{kg}^{-1}$. Postpartum period was uneventful without any hemorrhage.

Case 2; a 33 year-old woman had spontaneous vaginal birth with IV infusion of VWF/F VIII concentrate 40 IU $\mathrm{kg}^{-1}$. Patient was admitted on the postpartum $13^{\text {th }}$ day because of abnormal vaginal bleeding and epistaxis. She was treated with 3000 IU vWF/F VIII C, tranexamic acid (TXA) $4 \times 1$ gram (g), three units (U) of $\mathrm{RBC}$ (red blood cell) due to ongoing bleeding with $\mathrm{Hb}$ : $7 \mathrm{~g} \mathrm{dL}^{-1}$. One week later the patient was re-admitted to the ICU due to vaginal bleeding. She received 3000 IU vWF/FVIII, TXA 4x1 g, methyl-ergonovine $0.125 \mathrm{mg}$ and $1 \mathrm{U}$ of RBC transfusion (meanwhile $\mathrm{Hb}$ 7.3 was $\mathrm{g} \mathrm{dL}^{-1}$ ) and discharged after 6 days. She was prescribed oral contraceptive (ethinyl estradiol 30 $\mathrm{mcg}+$ desogestrel $150 \mathrm{mcg} 2 \times 1$ ). Four years later due to abnormal vaginal bleeding, cervical cauterisation was performed along with infusing vWF/factor VIII (2x2000 U of vWF/F VIII concentrate). Based on the pathological report revealing high grade squamous intraepithelial lesion, abdominal hysterectomy was planned under general anesthesia. Since her factor levels were very low (Table I), she received preoperatively $2 \times 4000$ of $\mathrm{VWF} / \mathrm{F}$ VIII concentrate and followed by $3 \mathrm{U}$ of RBC and FFP transfusion intraoperatively because of ongoing bleeding. Patient was discharged to the ward and no complication was observed in the short-term hospital followup. However, after three weeks patient was readmitted because of vaginal cuff bleeding again. She was treated with $3000 \mathrm{U}$ of VWF/F VIII concentrate followed up in ICU and was discharged with oral contraceptive and TXA prescription.

Case 3; a 29 year-old term parturient with VWD, was admitted for CS after hematology referral. Patient's factor levels at the end of the pregnancy were within

Table I. Laboratory results

\begin{tabular}{lccc}
\hline & FVIII (\%) & $\begin{array}{c}\text { vWF antigen } \\
\text { (\%) }\end{array}$ & $\begin{array}{c}\text { vWF/ristocetin } \\
\text { cofactor (\%) }\end{array}$ \\
\hline Case 1 (type 1) & 47 & 30 & 32 \\
Case 2 (type 2) & 1.2 & 3.2 & 1.7 \\
Case 3 (unknown type) & 97 & 104 & 150 \\
\hline
\end{tabular}

Normal reference: $50-100 \%$ normal range (Table I). She underwent general anesthesia using thiopentone and succinylcholine (intubation with $7.0 \mathrm{~mm}$ cuffed tube) and anesthesia maintained with sevoflurane in 50\% oxygen-air mixture. After delivery, uterotonics (oxytocine and carbetocine) and TXA were given intravenously. Intravenous paracetamol $1 \mathrm{~g}$ and morphine with PCA were administered for postoperative analgesia. Perioperative period and extubation was uneventful without need for any blood or factor transfusion.

\section{DISCUSSION}

In this case report, successful management of 3 patients with VWD (two of them had CS under general anesthesia and one had spontaneous vaginal birth) was presented.

Von Willebrand factor is multimeric plasma glycoprotein produced by megakaryocytes and endothelial cells which is crucial for hemostasis. The VWF, which is a carrier glycoprotein for FVIII (secondary hemostasis), mediates the attachment of platelets to the damaged endothelium (primary hemostasis) ${ }^{(4)}$. According to the current classification, VWD has three main types (Table II) ${ }^{(5)}$. Type 1 has partial deficiency of the factor and responsible from $70 \%$ of cases of a normal VWF, quantitative reduction (reduced VWF antigen and cofactor) but the multimers are normal, and Factor VIII is proportionally reduced but not as much as VWF ${ }^{(6)}$. FVIII and VWF levels increase and reach the normal value in most pregnant women with type $1^{(4)}$. In type 2 , there is a qualitative defect in VWF and divided as subtype $2 \mathrm{~A}$ or $2 \mathrm{~B}$ (mild thrombocytopenia accompanies). Type 3 is the most rare and severe form of VWD manifest with complete absence of vWF. FVIII and vWF levels never increase in pregnant women with VWD and needs strict follow up of bleeding and its treatment. Both type 2 and 3 patients should be managed by a multidisciplinary team at a tertiary center because

Table II. Classification of vWD and bleeding tendency

\begin{tabular}{lll}
\hline Type & Pathology & Bleeding tendency \\
\hline 1 & Quantitative decrease in vWF & Mild \\
2A & Qualitative decrease in vWF & Mild-moderate \\
2B & $\begin{array}{l}\text { Qualitative decrease in vWF and mild } \\
\text { thrombocytopenia }\end{array}$ & Mild-moderate \\
3 & Complete absence of vWF & Severe \\
\hline
\end{tabular}


of mild-moderate to severe bleeding tendency. If the baseline levels of both VWF and FVIII $>30 \mathrm{U} \mathrm{dL}^{-1}$, it will probably reach normal at the end of pregnancy. Thus, specific anti-hemorrhagic prophylaxis is rarely needed ${ }^{(7)}$.

In a recent retrospective analysis of 106 deliveries among 71 individual vWD patients at a large tertiarycare center, there were 54 vWD type 1, 6 vWD type 2, and 11 vWD type unknown. Forty-three cases $(40.6 \%)$ underwent cesarean deliveries and neuraxial techniques were performed in 94 of all 106 deliveries (88.7\%). Treatment with DDVAP or VWF/ factor VIII concentrate before neuraxial anesthesia was used in 27 out of 94 of parturients $(28.7 \%)$. Eleven deliveries (10.4\%) were complicated by postpartum hemorrhage with an as estimated blood loss of $\geq 1000 \mathrm{~mL}$. No adverse anesthetic outcomes including neuraxial hematoma or thromboembolic events were noted. This suggests that neuraxial anesthesia/analgesia can be safely performed with multidisciplinary appropriate pretreatment based on the type and severity of VWD ${ }^{(8)}$. In patients with type 2 disease, neuraxial block may be considered if the vWF and factor VIII levels are normal but it should be avoided in patients with type 3 disease (9). Our management for VWD varied case by case on the basis of predelivery factor levels. In our first case, since preoperative factor levels were lower than normal reference limits, she underwent CS under general anesthesia after she was given VWF/F VIII concentrate. In the second case factor levels were extremely low, she had vaginal birth and received VWF/F VIII concentrate replacement and discharged. However, she had postpartum bleeding twice requiring admission to hospital to treat with vWF/F VIII concentrate and transfusion. Eventually, she underwent total abdominal hysterectomy under general anesthesia via multidisciplinary approach and patient required VWF/F VIII concentrate replacement and transfusion many times. Our third patient's type was unknown but both factor levels at the end of the pregnancy was totally normal and factor replacement therapy wasn't given preoperatively. We didn't observe any bleeding after surgery and postpartum period without need for factor replacement as we expected. None of our cases had thrombocytopenia.

According to the specific perioperative management recommendations; DDAVP is first line treatment for minor bleeding surgery, replacement of VWF with plasma derived products for major bleeding surgery and antifibrinolytic drugs as hemostatic adjuncts ${ }^{(10)}$. Based on these three cases (type 1, 2 and unknown vWD), preoperative factor level determination and medical bleeding history guided us for preoperative factor replacement therapy and peroperative transfusion requirement.

In conclusion vWD parturients with bleeding symptoms can be admitted repetitively, therefore any parturient with VWD scheduled for surgery and/or delivery needs careful antenatal evaluation and postpartum follow up in tertiary care centers by multidisciplinary approach where blood and/or factor concentrates readily available.

Conflict of Interest: None

Informed Consent: Obtained

\section{REFERENCES}

1. Nichols WL, Hultin MB, James $A H$, et al. von Willebrand Disease (VWD): evidence-based diagnosis and management guidelines, the National Heart Lung Blood Institute (NHLBI) Expert Panel report (USA). Haemophilia. 2008;14:171-232. https://doi.org/10.1111/j.1365-2516.2007.01643.x

3. Leebeek FWG, Eikenboom JCJ. Von Willebrand's Disease. N Engl J Med. 2017;376:701-2. https://doi.org/10.1056/NEJMc1616060

4. Castaman G, James PD. Pregnancy and delivery in women with von Willebrand disease. Eur J Haematol. 2019;103:73-9. https://doi.org/10.1111/ejh.13250

5. Laffan MA, Lester W, O'Donnell JS, et al. The diagnosis and management of von Willebrand disease: a United Kingdom Haemophilia Centre Doctors Organization guideline approved by the British Committee for Standards in Haematology. $\mathrm{Br} J$ Haematol. 2014;167:453-65. https://doi.org/10.1111/bjh.13064

6. Echahdi H, El Hasbaoui B, El Khorassani M, Agadr A, Khattab M. Von Willebrand's disease: case report and review of literature. Pan Afr Med J. 2017;27:147. https://doi.org/10.11604/pamj.2017.27.147.12248

7. Castaman G. Changes of von Willebrand Factor during Pregnancy in Women with and without von Willebrand Disease. Mediterr J Hematol Infect Dis. 2013;5:e2013052. https://doi.org/10.4084/mjhid.2013.052

8. Reale SC, Farber MK, Lumbreras-Marquez MI, Connors JM, Carabuena JM. Anesthetic Management of Von Willebrand Disease in Pregnancy: A Retrospective Analysis of a Large Case Series. Anesth Analg. 2021 Apr 29. 
https://doi.org/10.1213/ANE.0000000000005502. Online ahead of print.

9. Pavord S, Rayment R, Madan B, et al. On behalf of the Royal College of Obstetricians and Gynaecologists. Management of inherited bleeding disorders in pregnancy. Green-top Guideline No 71. Br J Obstet Gynaecol. 2017;124:e193-e263. https://doi.org/10.1111/1471-0528.14592

10. Kozek-Langenecker SA, Ahmed AB, Afshari A, et al. Management of severe perioperative bleeding: guidelines from the European Society of Anaesthesiology. Eur J Anaesthesiol. 2017;34:332-95. https://doi.org/10.1097/EJA.0000000000000630 